\title{
Differences in life history characteristics between two sibling species in Brachionus calyciflorus complex from tropical shallow lakes
}

\author{
Xue Ling Wang, Xian Ling Xiang*, Meng Ning Xia, Ying Han, Lin Huang and Yi Long Xi
}

Key Laboratory of Biotic Environment and Ecological Safety in Anhui Province, College of Life Sciences, Anhui Normal University, Wuhu 241000, Anhui, China

Received 18 January 2014; Accepted 5 September 2014

\begin{abstract}
The studies of differences in life history and suitability of both water temperatures and trophic levels among rotifer sibling species improve our understanding of speciation, sibling species coexistence and possible niche differentiation over space and time, and consequences for the functioning of ecosystems induced by climate change and eutrophication. We collected Brachionus calyciflorus from Lake Baixiang and Lake Kongque, two tropical shallow lakes, in Xishuangbanna city, Yunnan, China, clonally cultured them in laboratory, and found that the B. calyciflorus complex contains two sibling species named sibling species BNA13 and BNB3 by phylogenetic analysis, and investigated the life-table parameters of the two sibling species BNA13 and BNB3 at four temperatures (16, 20, 24 and $\left.28^{\circ} \mathrm{C}\right)$ and four algal densities $(0.5,1.0,2.0$ and $4.0 \times 10^{6}$ cells. $\left.\mathrm{mL}^{-1}\right)$. The results showed that the responses to increasing temperature and algal density for each of the life-table parameters differed with rotifer sibling species. Sibling species, temperature, algal density and their interactions almost all significantly affected the durations of juvenile period, embryonic development, reproductive period, post-reproductive period, mean lifespan, net reproductive rate, generation time and intrinsic rate of population growth. Sibling species significantly affected the age-specific survivorship. Temperature, algal density and their interaction and the interaction of sibling species and temperature significantly affected the age-specific fecundity. Regardless of the effects of temperature and algal density, the durations of juvenile period, embryonic development, reproductive period, post-reproductive period and mean lifespan, age-specific survivorship, net reproductive rate and generation time of the B. calyciflorus sibling species BNA13 were greater than those of BNB3, but the intrinsic rate of population growth of BNA13 was lower than those of BNB3. This suggests that the two B. calyciflorus sibling species adopted variable life history strategies, low population growth and high survivorship for sibling species BNA13, and high population growth and low survivorship for sibling species BNB3. Both the intrinsic rates of population growth of BNA13 and BNB3 were the highest at $28^{\circ} \mathrm{C}$ and $4.0 \times 10^{6}$ cells.mL ${ }^{-1}$ algal density, indicating that some adaptations of the B. calyciflorus sibling species BNA13 and BNB3 in tropical shallow lakes to water temperatures and trophic levels were similar, and they have the potential for coexistence in single waterbody of higher temperature and higher trophic level.
\end{abstract}

Key words: Rotifer / Brachionus calyciflorus species complex / sibling species / life history characteristics / temperature / algal density / interspecific divergence

\section{Introduction}

Cryptic species (sibling species) are two or more distinct species that were classified as a single species due to their morphological similarity (Pfenninger and Schwenk, 2007). In the past two decades, facilitated through technical advances such as PCR and direct DNA sequencing,

\footnotetext{
*Corresponding author: xiangxianling@163.com
}

many phylogenetic, phylogeographic and population genetic studies discovered many cryptic lineages, which were genetically divergent, but morphologically similar (Pfenninger and Schwenk, 2007). Cryptic species are distributed among major metazoan taxa including rotifers such as Brachionus plicatilis, Keratella cochlearis, Brachionus calyciflorus, Epiphanes senta, Rotaria rotatoria and some categories of Adineta (Gómez and Serra, 1995; Gómez and Snell, 1996; Ciros-Pérez et al., 2001a; Gómez et al., 2002; 


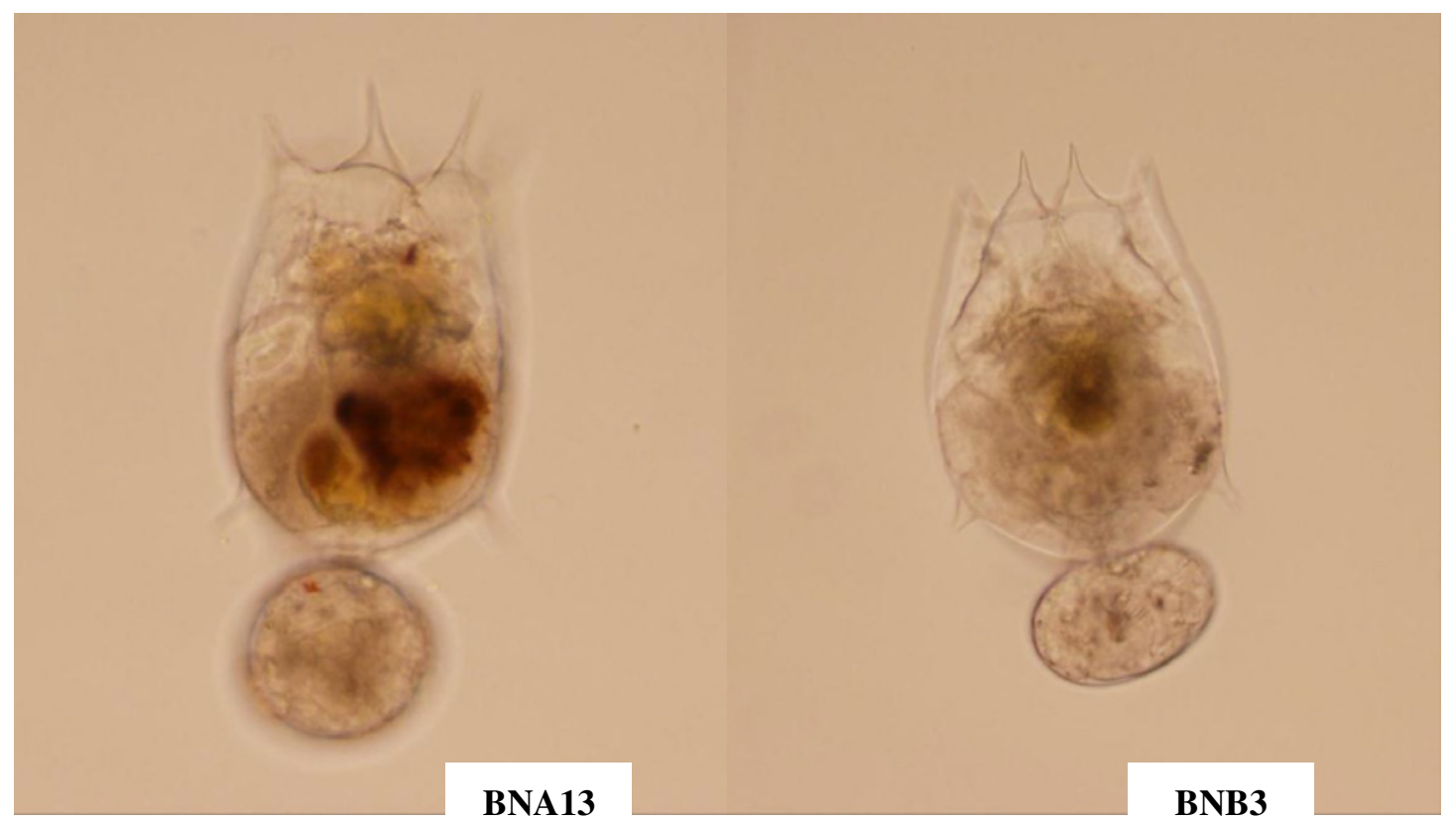

Fig. 1. Morphological characteristics of the B. calyciflorus sibling species BNA13 and BNB3 $(200 \times)$.

Derry et al., 2003; Gilbert and Walsh, 2005; Cheng et al., 2008; Li et al., 2008; Fontaneto et al., 2009, 2011; Li et al., 2010; Xiang et al., 2010, 2011a, 2011b). The research of cryptic species, especially rotifer cryptic species, not only are needed for studying species diversity, but also help us understand the mechanisms of species coexistence, niche differentiation and speciation.

Rotifers are a group of mostly, if not entirely freeliving, planktonic pseudocoelomates characterized by possessing a wheel of cilia called a corona at the anterior end (Zou, 2003). They occur in almost all types of waterbodies worldwide (Segers, 2008) and play an important role in many freshwater ecosystems (Wallace et al., 2006). Most studies about rotifer cryptic species are focused on the $B$. plicatilis complex. Previously thought to be a single cosmopolitan species due to their morphological similarity (Walker, 1981), the B. plicatilis complex apparently contains at least 14 species (Suatoni et al., 2006). Three of them, B. plicatilis (Müller) sensu stricto, $B$. ibericus and B. rotundiformis (Tschugunoff), co-occur in small ponds on the Mediterranean coast of Spain (Gómez et al., 1995; Ortells et al., 2003). Their morphology (Gómez et al., 1995; Ciros-Pérez et al., 2001a), reproduction (Carmona et al., 1995; Gómez et al., 1997) and ecological specialization (Gómez et al., 1995, 1997; Ciros-Pérez et al., 2001b; Lapesa et al., 2002; MonteroPau et al., 2011; Montero-Pau and Serra, 2011) have been described in details. Up to date, however, there are fewer reports about B. calyciflorus complex. In eastern China, the $B$. calyciflorus species complex contains at least eight cryptic species (Xiang et al., 2011b). Li et al. (2008) found three cryptic species in $B$. calyciflorus species complex in three subtropical waterbodies, Wuhu, China. Subsequently, Li et al. (2009) compared the life history characteristics of the three $B$. calyciflorus sibling species, and found differences not only in life-table parameters among the three sibling species but also in their responses of life-table parameters to increasing temperatures. But they did not provide information about developmental phases such as durations of juvenile period, embryonic development, reproductive period and post-reproductive period of $B$. calyciflorus sibling species. In our previous study, we found two $B$. calyciflorus lineages provisionally named BNA13 lineage (sequence number: KJ862225) in Lake Baixiang and BNB3 lineage (sequence number: KJ862229) (Fig. 1) in Lake Kongque, Xishuangbanna, China, by sequencing and analyzing the phylogeny of mtDNA COI genes (percent divergence was 13.2\%) of 24 clones in $B$. calyciflorus complex (unpublished data). Although formal taxonomic description of the lineages as distinct species remains to be conducted, due to the high genetic divergence and the phenotypic differences we report in this study, we here refer to these lineages as sibling species BNA13 and BNB3 in anticipation that future work will reveal them to be distinct species. However, the differences in their life-table parameters including principal developmental phases and their responses to changing temperature and algal food density remain unknown.

Life tables provide birth rates and death rates in an age-specific way. Therefore, life history variables such as average lifespan, generation time and population growth rate related to survivorship and reproduction can be quantified (Wallace et al., 2006) and provide valuable insights into the suitability of the ambient conditions for the zooplankton (Stearns, 1976). So, life-table demography is an important approach in understanding the life history strategy and population dynamics of zooplankton under continuously changing environmental conditions (Xi et al., 2013). 
The main purposes of the present study were to: (1) assess the responses in life-table parameters including developmental phases of the two B. calyciflorus sibling species from Lakes Baixiang and Kongque, Xishuangbanna, China, two tropical shallow lakes, respectively, to changing water temperature and algal density; (2) test whether ecological differences exist in life history characteristics between the two B. calyciflorus sibling species, which were genetically divergent; (3) compare differences in life-table parameters including developmental phases between the two B. calyciflorus sibling species at different temperatures $(16,20,24$ and $\left.28^{\circ} \mathrm{C}\right)$ and food densities $\left(0.5,1.0,2.0\right.$ and $4.0 \times 10^{6}$ cells. $\mathrm{ml}^{-1}$ ).

\section{Materials and methods}

B. calyciflorus sibling species BNA13 and BNB3 were isolated in October, 2012 from Lake Baixiang $\left(22^{\circ} 00^{\prime} 704^{\prime \prime} \mathrm{N}, \quad 100^{\circ} 47^{\prime} 456^{\prime \prime} \mathrm{E}\right)$ and Lake Kongque $\left(22^{\circ} 00^{\prime} 621^{\prime \prime} \mathrm{N}, 100^{\circ} 47^{\prime} 714^{\prime \prime} \mathrm{E}\right)$, respectively, in Xishuangbanna city, Yunnan, China and then clonally cultured under controlled laboratory conditions. Stock rotifer cultures were kept under static-renewal conditions with natural light at $24 \pm 1{ }^{\circ} \mathrm{C}$ in an illumination incubator and daily fed on algae Scenedesmus obliquus at $1.0-2.0 \times 10^{6}$ cells. $\mathrm{mL}^{-1}$ using EPA medium ( $\left.\mathrm{pH} 7.4-7.8\right)$ (Peltier and Weber, 1985) for about 6 months.

Before the experiments commenced, sibling species BNA13 and BNB3 were precultured in EPA medium and fed on $0.5,1.0,2.0$ and $4.0 \times 10^{6}$ cells. $\mathrm{mL}^{-1}$ of $S$. obliquus at $16,20,24$ and $28^{\circ} \mathrm{C}$, respectively, for at least 1 week. Algae grown in a semi-continuous culture using HB-4 medium (Li et al., 1959) renewed daily at $40 \%$ were centrifuged in exponential growth and resuspended in EPA medium (prepared by dissolving $96 \mathrm{mg} \mathrm{NaHCO}_{3}$, $60 \mathrm{mg} \mathrm{CaSO}_{4}, 60 \mathrm{mg} \mathrm{MgSO}_{4}$, and $4 \mathrm{mg} \mathrm{KCl}$ in $1 \mathrm{~L}$ of distilled water) and then stored at $4{ }^{\circ} \mathrm{C}$. The density of the stock algal concentrate was estimated using a hemocytometer (Tiefe, 0, $100 \mathrm{~mm}, 1 / 400 \mathrm{qmm}$, Germany).

Life-table experiments were conducted in 24-well tissue culture plates and started by introducing one amictic neonate $(<2 \mathrm{~h}$ old $)$ into each well which contained $0.5 \mathrm{ml}$ EPA medium with $0.5,1.0,2.0$ and $4.0 \times 10^{6}$ cells. $\mathrm{mL}^{-1}$ of S. obliquus at $16,20,24$ and $28^{\circ} \mathrm{C}$. We used 48 rotifers at every temperature and algal density. The rotifers were checked every $3 \mathrm{~h}$ during the initial $96 \mathrm{~h}$ at 16 and $20^{\circ} \mathrm{C}$ or $48 \mathrm{~h}$ at 24 and $28^{\circ} \mathrm{C}$ and all algal densities, and the time of the first egg and neonate produced was recorded, respectively. Thereafter, the rotifers were observed at 16 and $20^{\circ} \mathrm{C}$ every $12 \mathrm{~h}$, at 24 and $28^{\circ} \mathrm{C}$ every $8 \mathrm{~h}$, the numbers of eggs and neonates produced and original individuals alive were recorded respectively and then neonates were removed. Before each individual of every cohort died in the life-table experiments, the original rotifers alive were transferred into freshly prepared test solution every $24 \mathrm{~h}$.
Based on the data collected, the durations of juvenile period (the time between a neonate and that laying the first egg), embryonic development (the time between an adult laying an egg and that egg hatching), reproductive period (the time between an adult laying the first egg and the last egg) and post-reproductive period (the time between an adult laying no egg and that death) and mean lifespan (the average surviving time of all females) of the B. calyciflorus sibling species BNA13 and BNB3 grown at four temperatures and four algal densities were calculated. The age-specific survivorship $\left(l_{x}\right)$ and fecundity $\left(m_{x}\right)$ were constructed for each cohort using conventional life-table techniques ( $x$ was defined as the age interval, $l_{x}$ as the proportion surviving at the beginning of the age interval and $m_{x}$ as the number of offspring produced per female alive at the start of the age interval by the end of that interval; Poole, 1974), and net reproductive rate $\left(R_{0}=\sum_{0}^{\infty} l_{x} m_{x}\right.$; net population increase rate after a generation), generation time $\left(T=\frac{\sum l_{x} m_{x} x}{R_{0}}\right.$; the time between parental birth and offspring birth) and intrinsic rate of population growth $\left(\sum_{x=0}^{n} e^{-r_{m} x} l_{x} m_{x}=1 ; r_{\mathrm{m}}\right.$ was a maximum value of the rate of population increase under ideal conditions) of the two sibling species were also calculated according to Krebs (1985).

All data were tested for normality using the one-sample Kolmogorov-Smirnov procedure. The homogeneity of variances was checked using Levene's test. Three-way analyses of variance (ANOVAs) were conducted to evaluate the effects of sibling species, temperature, algal density and their interactions on each of the durations of principal developmental periods, mean lifespan, agespecific survivorship and fecundity, and the life-table demographic parameters. Multiple comparisons were conducted using least significant rank to determine which groups were significantly different among the four temperatures and four algal densities for each $B$. calyciflorus sibling species.

\section{Results}

\section{The effects on the durations of developmental stages of rotifer sibling species}

Sibling species, temperature, algal density and their interactions significantly affected the durations of juvenile period, embryonic development, reproductive period, post-reproductive period and mean lifespan $(P<0.05)$ except that algal density and the interaction of sibling species and algal density did not significantly affect the durations of post-reproductive period and embryonic development, respectively $(P>0.05)$ (three-way ANOVA). Regardless of the effects of temperature and algal density, the durations of juvenile period, embryonic development, reproductive period, post-reproductive period and mean lifespan of the B. calyciflorus sibling species BNA13 were greater than those of BNB3. 
Table 1. Durations of juvenile period (JP), embryonic development (ED), reproductive period (RP), post-reproductive period (PP) and mean lifespan (ML) of the two B. calyciflorus sibling species under different temperatures and algal densities (mean $\pm \mathrm{SE}$ ).

\begin{tabular}{|c|c|c|c|c|c|c|}
\hline $\begin{array}{l}\text { Sibling } \\
\text { species }\end{array}$ & Parameters & $\begin{array}{c}\text { Algal density } \\
\left(\times 10^{6} \text { cells } \cdot \mathrm{mL}^{-1}\right)\end{array}$ & $16^{\circ} \mathrm{C}$ & $20^{\circ} \mathrm{C}$ & $24^{\circ} \mathrm{C}$ & $28^{\circ} \mathrm{C}$ \\
\hline \multirow{20}{*}{ BNA13 } & \multirow[t]{4}{*}{ JP (h) } & 0.5 & $53.00 \pm 1.87^{\mathrm{Aa}}$ & $32.78 \pm 1.14^{\mathrm{Cc}}$ & $37.13 \pm 1.24^{\mathrm{Ab}}$ & $18.53 \pm 0.71^{\mathrm{ABd}}$ \\
\hline & & 1.0 & $50.35 \pm 1.76^{\mathrm{Ba}}$ & $39.00 \pm 0.95^{\mathrm{Ab}}$ & $30.39 \pm 1.34^{\mathrm{Bc}}$ & $19.17 \pm 0.60^{\mathrm{Ad}}$ \\
\hline & & 2.0 & $55.33 \pm 1.29^{\mathrm{Aa}}$ & $36.42 \pm 0.92^{\mathrm{ABb}}$ & $28.50 \pm 0.75^{\mathrm{BCc}}$ & $16.92 \pm 0.63^{\mathrm{BCd}}$ \\
\hline & & 4.0 & $45.73 \pm 1.16^{\mathrm{Ca}}$ & $36.22 \pm 0.92^{\mathrm{Bb}}$ & $25.71 \pm 0.57^{\mathrm{Cc}}$ & $15.80 \pm 0.48^{\mathrm{Cd}}$ \\
\hline & \multirow[t]{4}{*}{ ED (h) } & 0.5 & $24.59 \pm 0.81^{\mathrm{Ba}}$ & $22.76 \pm 1.11^{\mathrm{Aa}}$ & $14.47 \pm 0.85^{\mathrm{Ab}}$ & $9.83 \pm 0.34^{\mathrm{Bc}}$ \\
\hline & & 1.0 & $25.30 \pm 0.92^{\mathrm{Ba}}$ & $20.80 \pm 0.85^{\mathrm{ABb}}$ & $13.25 \pm 0.55^{\mathrm{Ac}}$ & $10.24 \pm 0.27^{\mathrm{Bd}}$ \\
\hline & & 2.0 & $26.33 \pm 1.39^{\mathrm{ABa}}$ & $19.74 \pm 0.90^{\mathrm{Bb}}$ & $13.42 \pm 0.91^{\mathrm{Ac}}$ & $10.23 \pm 0.42^{\mathrm{Bd}}$ \\
\hline & & 4.0 & $29.41 \pm 1.50^{\mathrm{Aa}}$ & $21.44 \pm 1.09^{\mathrm{ABb}}$ & $12.60 \pm 0.44^{\mathrm{Ac}}$ & $12.00 \pm 0.52^{\mathrm{Ac}}$ \\
\hline & \multirow[t]{4}{*}{ RP (h) } & 0.5 & $171.49 \pm 7.71^{\mathrm{Ba}}$ & $140.59 \pm 6.71^{\mathrm{Cb}}$ & $132.56 \pm 4.26^{\mathrm{Bb}}$ & $73.28 \pm 5.83^{\mathrm{Bc}}$ \\
\hline & & 1.0 & $188.46 \pm 8.35^{\mathrm{Ba}}$ & $152.18 \pm 6.64^{\mathrm{Cb}}$ & $137.69 \pm 6.39^{\mathrm{ABb}}$ & $71.22 \pm 5.74^{\mathrm{Bc}}$ \\
\hline & & 2.0 & $180.89 \pm 6.97^{\mathrm{Ba}}$ & $181.67 \pm 6.64^{\mathrm{Ba}}$ & $140.61 \pm 5.69^{\mathrm{ABb}}$ & $111.46 \pm 5.07^{\mathrm{Ac}}$ \\
\hline & & 4.0 & $215.34 \pm 8.21^{\mathrm{Aa}}$ & $234.17 \pm 8.09^{\mathrm{Aa}}$ & $153.26 \pm 6.85^{\mathrm{Ab}}$ & $126.66 \pm 4.47^{\mathrm{Ac}}$ \\
\hline & \multirow[t]{4}{*}{ PP (h) } & 0.5 & $55.02 \pm 5.03^{\mathrm{Ba}}$ & $46.83 \pm 2.61^{\mathrm{Ca}}$ & $31.29 \pm 2.57^{\mathrm{Ab}}$ & $34.00 \pm 3.57^{\mathrm{Ab}}$ \\
\hline & & 1.0 & $71.03 \pm 7.40^{\mathrm{ABa}}$ & $53.18 \pm 3.18^{\mathrm{BCb}}$ & $35.25 \pm 3.30^{\mathrm{Ac}}$ & $31.30 \pm 2.81^{\mathrm{Ac}}$ \\
\hline & & 2.0 & $69.00 \pm 7.07^{\mathrm{ABa}}$ & $60.56 \pm 4.26^{\mathrm{ABa}}$ & $34.00 \pm 3.50^{\mathrm{Ab}}$ & $19.69 \pm 1.86^{\mathrm{Bc}}$ \\
\hline & & 4.0 & $73.17 \pm 5.30^{\mathrm{Aa}}$ & $70.39 \pm 5.01^{\mathrm{Aa}}$ & $29.94 \pm 3.72^{\mathrm{Ab}}$ & $18.73 \pm 1.87^{\mathrm{Bb}}$ \\
\hline & \multirow[t]{4}{*}{ ML (h) } & 0.5 & $279.51 \pm 8.23^{\mathrm{Ca}}$ & $220.20 \pm 6.94^{\mathrm{Db}}$ & $200.98 \pm 4.15^{\mathrm{Ac}}$ & $125.80 \pm 5.57^{\mathrm{Bd}}$ \\
\hline & & 1.0 & $309.84 \pm 8.40^{\mathrm{Ba}}$ & $244.36 \pm 8.67^{\mathrm{Cb}}$ & $203.33 \pm 5.82^{\mathrm{Ac}}$ & $121.70 \pm 5.05^{\mathrm{Bd}}$ \\
\hline & & 2.0 & $305.22 \pm 8.49^{\mathrm{Ba}}$ & $278.65 \pm 8.46^{\mathrm{Bb}}$ & $203.11 \pm 6.11^{\mathrm{Ac}}$ & $148.08 \pm 4.62^{\mathrm{Ad}}$ \\
\hline & & 4.0 & $334.24 \pm 8.30^{\mathrm{Aa}}$ & $340.78 \pm 8.47^{\mathrm{Aa}}$ & $208.91 \pm 7.67^{\mathrm{Ab}}$ & $161.20 \pm 4.63^{\mathrm{Ac}}$ \\
\hline \multirow[t]{20}{*}{ BNB3 } & \multirow[t]{4}{*}{$\mathrm{JP}(\mathrm{h})$} & 0.5 & $49.08 \pm 1.38^{\mathrm{Aa}}$ & $33.44 \pm 1.37^{\mathrm{Ab}}$ & $17.86 \pm 0.60^{\mathrm{Ac}}$ & $15.63 \pm 0.35^{\mathrm{Bc}}$ \\
\hline & & 1.0 & $40.54 \pm 0.85^{\mathrm{Ca}}$ & $32.13 \pm 1.06^{\mathrm{Ab}}$ & $18.29 \pm 0.56^{\mathrm{Ac}}$ & $17.23 \pm 0.28^{\mathrm{Ac}}$ \\
\hline & & 2.0 & $43.65 \pm 0.85^{\mathrm{Ba}}$ & $31.22 \pm 0.63^{\mathrm{ABb}}$ & $18.00 \pm 0.35^{\mathrm{Ac}}$ & $17.04 \pm 0.33^{\mathrm{Ac}}$ \\
\hline & & 4.0 & $43.43 \pm 1.16^{\mathrm{Ba}}$ & $28.43 \pm 0.68^{\mathrm{Bb}}$ & $17.79 \pm 0.33^{\mathrm{Ac}}$ & $13.98 \pm 0.33^{\mathrm{Cd}}$ \\
\hline & \multirow[t]{4}{*}{ ED (h) } & 0.5 & $26.00 \pm 1.10^{\mathrm{Aa}}$ & $20.71 \pm 0.88^{\mathrm{Ab}}$ & $11.93 \pm 0.31^{\mathrm{Cc}}$ & $9.94 \pm 0.29^{\mathrm{ABd}}$ \\
\hline & & 1.0 & $22.31 \pm 0.45^{\mathrm{Ca}}$ & $20.73 \pm 1.19^{\mathrm{Aa}}$ & $12.29 \pm 0.22^{\mathrm{Cb}}$ & $10.85 \pm 0.31^{\mathrm{Ab}}$ \\
\hline & & 2.0 & $22.80 \pm 0.73^{\mathrm{BCa}}$ & $20.59 \pm 1.08^{\mathrm{Ab}}$ & $13.30 \pm 0.33^{\mathrm{Bc}}$ & $10.53 \pm 0.33^{\mathrm{Ad}}$ \\
\hline & & 4.0 & $25.07 \pm 1.10^{\mathrm{ABa}}$ & $19.73 \pm 0.77^{\mathrm{Ab}}$ & $15.64 \pm 0.50^{\mathrm{Ac}}$ & $9.26 \pm 0.41^{\mathrm{Bd}}$ \\
\hline & \multirow[t]{4}{*}{$\mathrm{RP}(\mathrm{h})$} & 0.5 & $117.38 \pm 5.80^{\mathrm{Ba}}$ & $89.34 \pm 5.58^{\mathrm{Cb}}$ & $67.29 \pm 4.50^{\mathrm{Ac}}$ & $49.98 \pm 2.47^{\mathrm{Ad}}$ \\
\hline & & 1.0 & $125.00 \pm 4.81^{\mathrm{Ba}}$ & $103.00 \pm 5.30^{\mathrm{BCb}}$ & $72.19 \pm 3.44^{\mathrm{Ac}}$ & $51.72 \pm 2.58^{\mathrm{Ad}}$ \\
\hline & & 2.0 & $127.05 \pm 4.04^{\mathrm{Ba}}$ & $106.78 \pm 4.77^{\mathrm{Bb}}$ & $74.82 \pm 2.96^{\mathrm{Ac}}$ & $49.49 \pm 2.45^{\mathrm{Ad}}$ \\
\hline & & 4.0 & $152.29 \pm 10.33^{\mathrm{Aa}}$ & $122.48 \pm 4.48^{\mathrm{Ab}}$ & $67.55 \pm 2.92^{\mathrm{Ac}}$ & $54.77 \pm 2.31^{\mathrm{Ac}}$ \\
\hline & \multirow[t]{4}{*}{$\mathrm{PP}(\mathrm{h})$} & 0.5 & $18.77 \pm 1.75^{\mathrm{Ab}}$ & $31.90 \pm 2.28^{\mathrm{Aa}}$ & $17.52 \pm 1.85^{\mathrm{Ab}}$ & $21.56 \pm 1.82^{\mathrm{ABb}}$ \\
\hline & & 1.0 & $18.46 \pm 2.11^{\mathrm{Ab}}$ & $31.93 \pm 2.16^{\mathrm{Aa}}$ & $10.48 \pm 0.79^{\mathrm{Bc}}$ & $23.49 \pm 2.10^{\mathrm{Ab}}$ \\
\hline & & 2.0 & $15.00 \pm 0.94^{\mathrm{Ab}}$ & $27.57 \pm 2.07^{\mathrm{ABa}}$ & $9.27 \pm 0.52^{\mathrm{Bc}}$ & $18.72 \pm 1.76^{\mathrm{Bb}}$ \\
\hline & & 4.0 & $16.86 \pm 1.42^{\mathrm{Ab}}$ & $25.50 \pm 1.78^{\mathrm{Ba}}$ & $10.29 \pm 0.68^{\mathrm{Bc}}$ & $10.55 \pm 0.69^{\mathrm{Cc}}$ \\
\hline & \multirow[t]{4}{*}{ ML (h) } & 0.5 & $185.23 \pm 6.17^{\mathrm{Ba}}$ & $154.68 \pm 5.30^{\mathrm{Bb}}$ & $102.67 \pm 3.97^{\mathrm{Ac}}$ & $87.17 \pm 2.40^{\mathrm{ABd}}$ \\
\hline & & 1.0 & $184.00 \pm 5.74^{\mathrm{Ba}}$ & $167.07 \pm 5.77^{\mathrm{ABb}}$ & $100.95 \pm 3.34^{\mathrm{Ac}}$ & $92.45 \pm 2.62^{\mathrm{Ac}}$ \\
\hline & & 2.0 & $185.70 \pm 3.94^{\mathrm{Ba}}$ & $165.57 \pm 4.69^{\mathrm{ABb}}$ & $102.09 \pm 2.89^{\mathrm{Ac}}$ & $85.26 \pm 2.52^{\mathrm{Bd}}$ \\
\hline & & 4.0 & $212.57 \pm 10.28^{\mathrm{Aa}}$ & $176.40 \pm 4.98^{\mathrm{Ab}}$ & $95.62 \pm 2.59^{\mathrm{Ac}}$ & $79.30 \pm 1.99^{\mathrm{Cd}}$ \\
\hline
\end{tabular}

Multiple comparison of LSD. The different small and large letters indicate that there are significant differences among the groups in the same row and column, respectively, and a, b, c and d or A, B, C and D indicate that the means decrease gradually.

For the sibling species BNA13, at the same algal density, the duration of embryonic development, reproductive period, post-reproductive period and mean lifespan significantly shortened with increasing temperature $(P<0.05)$, but the duration of juvenile period changed with increasing temperature which depended on algal density. At the same temperature, the duration of reproductive period and mean lifespan prolonged with increasing algal density, but the other life history variables did not follow this rule (Table 1). The duration of juvenile period was the longest at $16^{\circ} \mathrm{C}$ and 0.5 and $1.0 \times 10^{6}$ cells. $\mathrm{mL}^{-1}$ algal density, which was similar $(P>0.05)$. The duration of embryonic development was the shortest at $28^{\circ} \mathrm{C}$ and $0.5,1.0$ and $2.0 \times 10^{6}$ cells. $\mathrm{mL}^{-1}$ algal density, which was similar $(P>0.05)$. Both the durations of reproductive period and mean lifespan were the longest at $4.0 \times 10^{6}$ cells. $\mathrm{mL}^{-1}$ algal density and 16 and $20^{\circ} \mathrm{C}$, and the shortest at $28^{\circ} \mathrm{C}$ and 0.5 and $1.0 \times 10^{6}$ cells. $\mathrm{mL}^{-1}$ algal density $(P>0.05$, Table 1$)$.

For the sibling species BNB3, at the same algal density, the duration of juvenile period, embryonic development, reproductive period and mean lifespan significantly shortened with increasing temperature $(P<0.05)$, but the duration of post-reproductive period changed with increasing temperature which depended on algal density. At the same temperature, the life history variables changed 


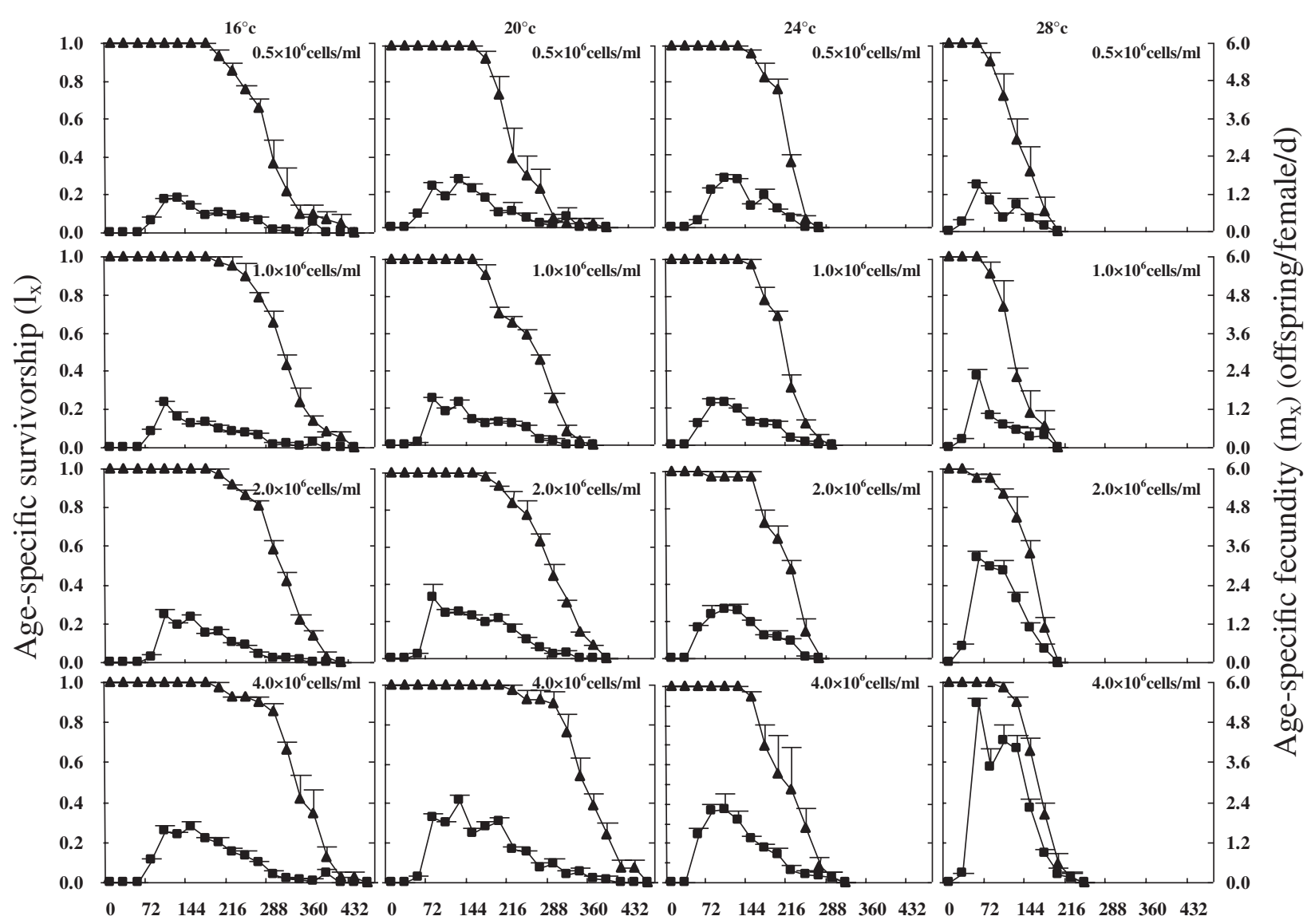

Age (h)

Fig. 2. Survivorship (triangle) and fecundity curves (square) of the B. calyciflorus sibling species BNA13 at four temperatures and algal densities.

with increasing algal density which depended on temperature (Table 1). The duration of juvenile period was the longest at $16^{\circ} \mathrm{C}$ and $0.5 \times 10^{6}$ cells.mL $\mathrm{mL}^{-1}$ algal density, and the shortest at $28^{\circ} \mathrm{C}$ and $4.0 \times 10^{6}$ cells. $\mathrm{mL}^{-1}$ algal density. The duration of reproductive period was the longest at $16^{\circ} \mathrm{C}$ and $4.0 \times 10^{6}$ cells.mL ${ }^{-1}$ algal density. The duration of mean lifespan was the longest at $16^{\circ} \mathrm{C}$ and $4.0 \times 10^{6}$ cells. $\mathrm{mL}^{-1}$ algal density, and at $28^{\circ} \mathrm{C}$ and $4.0 \times 10^{6}$ cells. $\mathrm{mL}^{-1}$ algal density, it was the shortest (Table 1).

\section{The effects on the survivorship and fecundity of rotifer sibling species}

Only sibling species significantly affected the agespecific survivorship $(P<0.05)$, other factors did not significantly affect it $(P>0.05)$ (three-way ANOVA). Temperature, algal density and their interaction and the interaction of sibling species and temperature significantly affected the age-specific fecundity $(P<0.05)$, but other factors did not significantly affect it $(P>0.05)$ (threeway ANOVA). Regardless of the effects of temperature and algal density, the age-specific survivorship of the B. calyciflorus sibling species BNA13 was longer or higher than those of BNB3. However, the age-specific fecundity of the B. calyciflorus sibling species BNA13 was lower than that of BNB3, but had no significant difference $(P>0.05)$.

The age-specific survivorship was similar at all temperatures and algal densities for sibling species BNA13 or BNB3 $(P>0.05$, Fig. 2). The age-specific fecundity of the sibling species BNA13 was the highest at $28^{\circ} \mathrm{C}$ and $4.0 \times 10^{6}$ cells. $\mathrm{mL}^{-1}$ algal density (Fig. 3 ).

\section{The effects on the population growth parameters of rotifer sibling species}

Sibling species, temperature, algal density and their interactions significantly affected the net reproductive rate, generation time and intrinsic rate of population growth $(P<0.05)$ except that the interaction of sibling species and algal density did not significantly affect the intrinsic rate of population growth $(P>0.05)$ (three-way ANOVA). Regardless of the effects of temperature and algal density, 


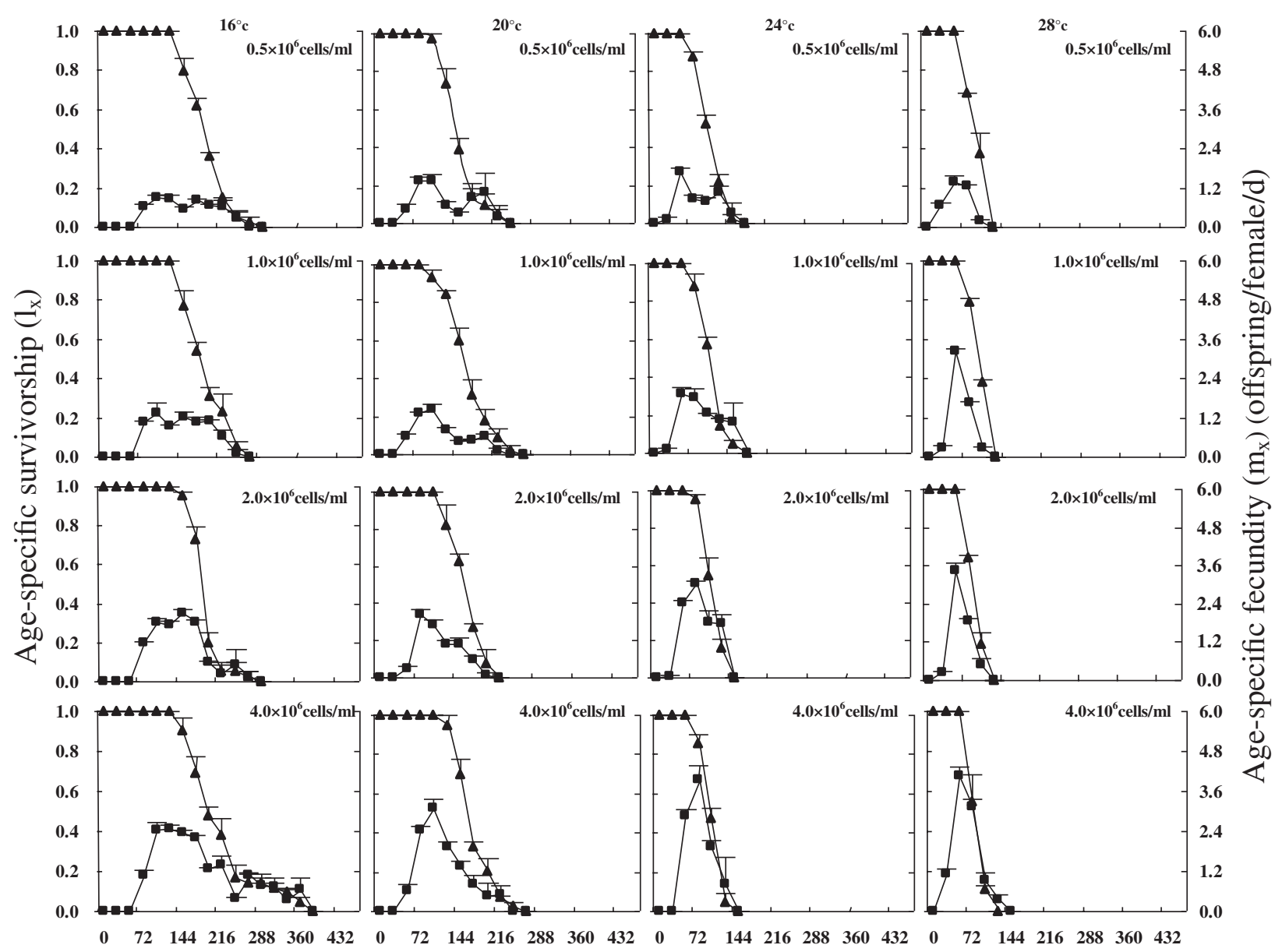

Age (h)

Fig. 3. Survivorship (triangle) and fecundity curves (square) of the B. calyciflorus sibling species BNB3 at four temperatures and algal densities.

the net reproductive rate and generation time of the B. calyciflorus sibling species BNA13 were greater than those of BNB3, but the intrinsic rate of population growth of BNA13 was lower than those of BNB3.

For the sibling species BNA13, at the same algal density, the generation time shortened with increasing temperature, but the intrinsic rate of population growth increased with increasing temperature. The net reproductive rate changed with increasing temperature which depended on algal density. At the same temperature, the net reproductive rate and intrinsic rate of population growth increased with increasing algal density. The generation time changed with increasing algal density which depended on temperature. At 16 and $24{ }^{\circ} \mathrm{C}$, the generation time had no significant differences among all algal densities $(P>0.05)$, but prolonged with increasing algal density at 20 and $28^{\circ} \mathrm{C}$. The net reproductive rate was the highest at $28^{\circ} \mathrm{C}$ and $4.0 \times 10^{6}$ cells. $\mathrm{mL}^{-1}$ algal density. The generation time was the shortest at $28^{\circ} \mathrm{C}$ and 0.5 and $1.0 \times 10^{6}$ cells. $\mathrm{mL}^{-1}$ algal density, which was similar $(P>0.05)$. The intrinsic rate of population growth was the highest at $28^{\circ} \mathrm{C}$ and $4.0 \times 10^{6}$ cells. $\mathrm{mL}^{-1}$ algal density, lowest at $16^{\circ} \mathrm{C}$ and $0.5,1.0$ and $2.0 \times 10^{6}$ cells.mL ${ }^{-1}$ algal density, which was similar $(P>0.05$, Table 2$)$.

For the sibling species BNB3, at the same algal density, the generation time shortened with increasing temperature, but the intrinsic rate of population growth increased with increasing temperature. The net reproductive rate changed with increasing temperature which depended on algal density. At 0.5 and $1.0 \times 10^{6}$ cells. $\mathrm{mL}^{-1}$ algal density, the net reproductive rate had no significant differences among four temperatures, but decreased with increasing temperature at 2.0 and $4.0 \times 10^{6}$ cells. $\mathrm{mL}^{-1}$ algal density. At the same temperature, the net reproductive rate and intrinsic rate of population growth increased with increasing algal density. The generation time changed with increasing algal density which depended on temperature. At 16 and $20^{\circ} \mathrm{C}$, the generation time prolonged with increasing algal density, but had no significant differences among four algal densities at 24 and $28^{\circ} \mathrm{C}(P>0.05)$. The net reproductive rate was the highest at $4.0 \times 10^{6}$ cells.mL ${ }^{-1}$ algal density and 16 and $20^{\circ} \mathrm{C}$, which was similar $(P>0.05)$. The generation time was the longest at $16^{\circ} \mathrm{C}$ and 
Table 2. Net reproductive rate $\left(R_{0}\right)$, generation time $(T)$ and intrinsic rate of population growth $\left(r_{\mathrm{m}}\right)$ of the two B. calyciflorus sibling species under different temperatures and algal densities (mean $\pm \mathrm{SE}$ ).

\begin{tabular}{|c|c|c|c|c|c|c|}
\hline $\begin{array}{l}\text { Sibling } \\
\text { species }\end{array}$ & Parameters & $\begin{array}{c}\text { Algal density } \\
\left(\times 10^{6} \text { cells } \cdot \mathrm{mL}^{-1}\right)\end{array}$ & $16^{\circ} \mathrm{C}$ & $20^{\circ} \mathrm{C}$ & $24^{\circ} \mathrm{C}$ & $28^{\circ} \mathrm{C}$ \\
\hline \multirow[t]{12}{*}{ BNA13 } & \multirow[t]{4}{*}{$R_{0}$ (ind.) } & 0.5 & $5.70 \pm 0.27^{\mathrm{Cab}}$ & $7.39 \pm 0.90^{\mathrm{Ca}}$ & $6.71 \pm 0.44^{\mathrm{Ba}}$ & $3.59 \pm 0.56^{\mathrm{Cb}}$ \\
\hline & & 1.0 & $6.34 \pm 0.25^{\mathrm{BCa}}$ & $6.90 \pm 0.14^{\mathrm{Ca}}$ & $6.39 \pm 0.48^{\mathrm{Ba}}$ & $4.28 \pm 0.35^{\mathrm{Cb}}$ \\
\hline & & 2.0 & $7.32 \pm 0.34^{\mathrm{Bb}}$ & $10.34 \pm 0.75^{\mathrm{Ba}}$ & $7.70 \pm 0.51^{\mathrm{Bb}}$ & $11.04 \pm 0.77^{\mathrm{Ba}}$ \\
\hline & & 4.0 & $10.29 \pm 0.60^{\mathrm{Ac}}$ & $14.66 \pm 0.65^{\mathrm{Ab}}$ & $10.70 \pm 1.11^{\mathrm{Ac}}$ & $18.74 \pm 1.41^{\mathrm{Aa}}$ \\
\hline & \multirow[t]{4}{*}{$T(\mathrm{~h})$} & 0.5 & $154.24 \pm 4.28^{\mathrm{Aa}}$ & $122.84 \pm 5.09^{\mathrm{Cb}}$ & $118.27 \pm 1.49^{\mathrm{Ab}}$ & $68.53 \pm 5.60^{\mathrm{Cc}}$ \\
\hline & & 1.0 & $152.86 \pm 3.23^{\mathrm{Aa}}$ & $132.25 \pm 2.82^{\mathrm{BCb}}$ & $109.51 \pm 0.25^{\mathrm{Ac}}$ & $65.06 \pm 4.13^{\mathrm{Cd}}$ \\
\hline & & 2.0 & $154.89 \pm 1.76^{\mathrm{Aa}}$ & $141.23 \pm 2.02^{\mathrm{Bb}}$ & $111.21 \pm 2.78^{\mathrm{Ac}}$ & $79.55 \pm 3.66^{\mathrm{Bd}}$ \\
\hline & & 4.0 & $162.02 \pm 0.45^{\mathrm{Aa}}$ & $156.16 \pm 3.68^{\mathrm{Aa}}$ & $108.64 \pm 5.20^{\mathrm{Ab}}$ & $86.67 \pm 1.40^{\mathrm{Ac}}$ \\
\hline & \multirow[t]{4}{*}{$r_{\mathrm{m}}($ per $\mathrm{d})$} & 0.5 & $0.3069 \pm 0.0164^{\mathrm{Bb}}$ & $0.4498 \pm 0.0224^{\mathrm{BCa}}$ & $0.4302 \pm 0.0166^{\mathrm{Ca}}$ & $0.4930 \pm 0.0447^{\mathrm{Da}}$ \\
\hline & & 1.0 & $0.3343 \pm 0.0133^{\mathrm{Bc}}$ & $0.4101 \pm 0.0030^{\mathrm{Cb}}$ & $0.4700 \pm 0.0231^{\mathrm{BCb}}$ & $0.6059 \pm 0.0376^{\mathrm{Ca}}$ \\
\hline & & 2.0 & $0.3441 \pm 0.0132^{\mathrm{Bc}}$ & $0.4848 \pm 0.0240^{\mathrm{ABb}}$ & $0.5232 \pm 0.0221^{\mathrm{Bb}}$ & $0.8905 \pm 0.0227^{\mathrm{Ba}}$ \\
\hline & & 4.0 & $0.4067 \pm 0.0110^{\mathrm{Ad}}$ & $0.5298 \pm 0.0075^{\mathrm{Ac}}$ & $0.6411 \pm 0.0388^{\mathrm{Ab}}$ & $1.0417 \pm 0.0252^{\mathrm{Aa}}$ \\
\hline \multirow[t]{12}{*}{ BNB3 } & \multirow[t]{4}{*}{$R_{0}$ (ind.) } & 0.5 & $3.68 \pm 0.13^{\mathrm{Da}}$ & $3.99 \pm 0.50^{\mathrm{Ca}}$ & $3.07 \pm 0.21^{\mathrm{Ba}}$ & $3.00 \pm 0.24^{\mathrm{Ca}}$ \\
\hline & & 1.0 & $5.39 \pm 0.61^{\mathrm{Ca}}$ & $4.35 \pm 0.26^{\mathrm{BCa}}$ & $4.46 \pm 0.44^{\mathrm{Ba}}$ & $4.91 \pm 0.06^{\mathrm{Ba}}$ \\
\hline & & 2.0 & $8.35 \pm 0.56^{\mathrm{Ba}}$ & $5.81 \pm 0.55^{\mathrm{Bbc}}$ & $6.63 \pm 0.26^{\mathrm{Ab}}$ & $4.98 \pm 0.28^{\mathrm{Bc}}$ \\
\hline & & 4.0 & $11.34 \pm 0.14^{\mathrm{Aa}}$ & $9.62 \pm 0.63^{\mathrm{Aa}}$ & $7.47 \pm 0.86^{\mathrm{Ab}}$ & $7.07 \pm 0.41^{\mathrm{Ab}}$ \\
\hline & \multirow[t]{4}{*}{$T(\mathrm{~h})$} & 0.5 & $123.80 \pm 3.16^{\mathrm{Ba}}$ & $92.39 \pm 2.05^{\mathrm{Bb}}$ & $63.94 \pm 1.45^{\mathrm{Ac}}$ & $51.00 \pm 1.18^{\mathrm{Ad}}$ \\
\hline & & 1.0 & $121.20 \pm 1.59^{\mathrm{Ba}}$ & $93.56 \pm 1.88^{\mathrm{Bb}}$ & $67.53 \pm 1.27^{\mathrm{Ac}}$ & $54.07 \pm 0.38^{\mathrm{Ad}}$ \\
\hline & & 2.0 & $123.70 \pm 2.69^{\mathrm{Ba}}$ & $96.71 \pm 0.64^{\mathrm{ABb}}$ & $68.74 \pm 2.71^{\mathrm{Ac}}$ & $53.76 \pm 0.99^{\mathrm{Ad}}$ \\
\hline & & 4.0 & $136.83 \pm 3.00^{\mathrm{Aa}}$ & $100.37 \pm 1.40^{\mathrm{Ab}}$ & $66.14 \pm 1.12^{\mathrm{Ac}}$ & $50.88 \pm 1.92^{\mathrm{Ad}}$ \\
\hline & \multirow[t]{4}{*}{$r_{\mathrm{m}}($ per $\mathrm{d})$} & 0.5 & $0.3264 \pm 0.0447^{\mathrm{Bb}}$ & $0.3860 \pm 0.0400^{\mathrm{Bb}}$ & $0.4561 \pm 0.03725^{\mathrm{BCab}}$ & $0.5598 \pm 0.0576^{\mathrm{Ca}}$ \\
\hline & & 1.0 & $0.3614 \pm 0.0231^{\mathrm{Bc}}$ & $0.4114 \pm 0.0104^{\mathrm{Bc}}$ & $0.5762 \pm 0.0518^{\mathrm{Bb}}$ & $0.7446 \pm 0.0129^{\mathrm{Ba}}$ \\
\hline & & 2.0 & $0.4479 \pm 0.0080^{\mathrm{Ab}}$ & $0.4706 \pm 0.0296^{\mathrm{Bb}}$ & $0.7134 \pm 0.0119^{\mathrm{ABa}}$ & $0.7539 \pm 0.0402^{\mathrm{Ba}}$ \\
\hline & & 4.0 & $0.4886 \pm 0.0086^{\mathrm{Ac}}$ & $0.6035 \pm 0.0251^{\mathrm{Ac}}$ & $0.8360 \pm 0.0799^{\mathrm{Ab}}$ & $1.0298 \pm 0.0458^{\mathrm{Aa}}$ \\
\hline
\end{tabular}

Multiple comparison of LSD. The different small and large letters indicate that there are significant differences among the groups in the same row and column, respectively, and ${ }^{\mathrm{a}},{ }^{\mathrm{b}},{ }^{\mathrm{c}}$ and ${ }^{\mathrm{d}}$ or ${ }^{\mathrm{A}},{ }^{\mathrm{B}},{ }^{\mathrm{C}}$ and ${ }^{\mathrm{D}}$ indicate that the means decrease gradually.

$4.0 \times 10^{6}$ cells. $\mathrm{mL}^{-1}$ algal density, and shortest at $28^{\circ} \mathrm{C}$ and all algal densities, which was similar $(P>0.05)$. The intrinsic rate of population growth was the highest at $28^{\circ} \mathrm{C}$ and $4.0 \times 10^{6}$ cells. $\mathrm{mL}^{-1}$ algal density (Table 2 ).

\section{Discussion}

Previously it was demonstrated that there were significant differences in life-table parameters between rotifer species or strains (Ricci, 1991; Dong et al., 2004; Feng and Xi, 2004; Xi et al., 2005). Li et al. (2009) also found the differences among the sibling species HE1, HE3 and LE9 in the B. calyciflorus species complex. The reasons of the significant differences in life-table parameters among rotifers depended on genetic factors. In the present study, almost all the life-table parameters of the $B$. calyciflorus sibling species BNA13 were significantly different from those of BNB3. Our results not only confirmed the above conclusions, but also again provided ecologically characteristic evidences for $B$. calyciflorus sibling species determination.

Changes in life history traits of Brachionus in relation to kairomones from predators facilitated the coexistence of prey with predators (Gilbert, 1999). A greater investment in reproduction by rotifers often lowered survivorship (Sarma et al., 2002). Garcia et al. (2007) suggested that the strategy of low reproduction and high survivorship adopted by $B$. havanaensis in the presence of the copepod predator Acanthocyclops robustus was due to the fact that the copepod feeds on B. havanaensis in lower numbers than vertebrate predators. Guo et al. (2011) also found that resource allocation to growth and reproduction seemed to be flexible and responsive to competition or/and predation risk. The rotifer $B$. calyciflorus seemed to use low reproduction and high survivorship versus high reproduction and low survivorship based on the presence of predators and competitors respectively. In our study, the life-table parameters including the durations of juvenile period, embryonic development, reproductive period, post-reproductive period and mean lifespan, agespecific survivorship, net reproductive rate and generation time of the $B$. calyciflorus sibling species BNA13 were all greater than those of $\mathrm{BNB} 3$, but the intrinsic rate of population growth of BNA13 was lower than that of BNB3.This indicates that the two B. calyciflorus sibling species also used variable life history strategies, low population growth and high survivorship for sibling species BNA13, and high population growth and low survivorship for sibling species BNB3. It also suggested the assumption that different life history strategies of the two B. calyciflorus sibling species BNA13 and BNB3 could be the adaptation to competition or/and predation risk. However, further researches are needed for discriminating 
the relationships of life history strategy and competition as well as predation risk for sibling species BNA13 and BNB3.

Various factors, including temperature, food quality and quantity affect survival and reproduction of rotifers. The results of previous studies showed that the differences of life-table parameters between or among rotifers varied with temperature (Hu et al., 2008; Tao et al., 2008; Xi et al., 2013) or temperature and algal density (PérezLegaspi and Rico-Martínez, 1998). Among rotifer sibling species, Li et al. (2009) studied the differences of life-table parameters of sibling species HE1, HE3 and LE9 in the $B$. calyciflorus species complex varied with temperature. The results showed that the responses in life-table parameters to increasing temperatures were also different among the three sibling species. But the above mentioned results did not involve developmental phases such as the durations of juvenile period, embryonic development, reproductive period, and post-reproductive period of rotifers. In our study, we explored not only the net reproductive rate, generation time, and intrinsic rate of population growth, but also the durations of juvenile period, embryonic development, reproductive period and post-reproductive period of the two B. calyciflorus sibling species. The similar results were obtained in this study.

The rate of population growth of poikilothermal animals depends on the metabolic rate, which increases with temperature, but the net reproductive rate should be unchanged by temperature (Fanestil and Barrows, 1965; Meadow and Barrows, 1971). In fact, the net reproductive rates of many tested rotifer species or sibling species or strains were significantly affected by temperature (Pérez-Legaspi and Rico-Martínez, 1998; Dong et al., 2004; Xi et al., 2005, 2013; Hu et al., 2008; Tao et al., 2008; Li et al., 2009). In the present study, the net reproductive rates of the two B. calyciflorus sibling species BNA13 and BNB3 were also affected by temperature. Genetic effects were the important endogenous factors in a prior study of Li et al. (2009) and may apply to B. calyciflorus sibling species BNA13 and BNB3 as well. However, further research is needed to determine how temperature affects their reproductive rates and why rotifers do not follow common trends for poikilothermal animals.

Intrinsic rate of population growth is frequently considered as a short-term fitness measure of a rotifer species, representing its ability to grow in a particular environment (Stelzer, 2005; Campillo et al., 2011). The responses of intrinsic rate of population growth to increasing temperatures were depended on rotifer species and algal food density. The intrinsic rates of population growth of $B$. havanaensis, B. rubens, B. urceolaris, $B$. forcatus and B. caudatus all significantly increased with temperature (Pavón-Meza et al., 2005; Hu et al., 2008; Tao et al., 2008). Similarly, the intrinsic rate of population growth of the sibling species LE9 in B. calyciflorus complex from Wuhu, China was the highest at $28^{\circ} \mathrm{C}$, at 13 and $18^{\circ} \mathrm{C}$ it was the lowest. Where the sibling species $\mathrm{HE} 3$ is concerned, it was the highest at 23 and $28^{\circ} \mathrm{C}$. However, the intrinsic rate of population growth of the sibling species HE1 was similar at 13,18 and $28^{\circ} \mathrm{C}$ (Li et al., 2009). Temperature did not significantly affect the intrinsic rate of population growth of $B$. diversicornis at $1.0,3.0$ and $5.0 \times 10^{6}$ cells. $\mathrm{mL}^{-1}$ algal density (Ning et al., 2013). In this study, we obtained the analogous results. The intrinsic rate of population growth of B. calyciflorus sibling species BNA13 was the highest at $28^{\circ} \mathrm{C}$ and $4.0 \times 10^{6}$ cells. $\mathrm{mL}^{-1}$ algal density, lowest at $16^{\circ} \mathrm{C}$ and $0.5,1.0$ and $2.0 \times 10^{6}$ cells.mL ${ }^{-1}$ algal density, which was similar. The intrinsic rate of population growth of $B$. calyciflorus sibling species BNB3 was also the highest at $28^{\circ} \mathrm{C}$ and $4.0 \times 10^{6}$ cells.mL $\mathrm{mL}^{-1}$ algal density. Obviously, both the intrinsic rates of population growth of B. calyciflorus sibling species BNA13 and BNB3 were the highest at $28^{\circ} \mathrm{C}$ and $4.0 \times 10^{6}$ cells. $\mathrm{mL}^{-1}$ algal density, indicating that some adaptations of the $B$. calyciflorus sibling species BNA13 and BNB3 in tropical shallow lakes to water temperatures and trophic levels were similar. The results of this study suggest coexistence of the B. calyciflorus sibling species BNA13 and BNB3 is possible in single waterbody of higher temperature and higher trophic level.

\section{Conclusion}

The responses to increasing temperature and algal density in each of the life-table parameters differed with rotifer B. calyciflorus sibling species. Sibling species, temperature, algal density and their interactions almost all significantly affected life history variables of rotifers. Regardless of the effects of temperature and algal density, the age-specific survivorship of the $B$. calyciflorus sibling species BNA13 was greater than those of BNB3, but the intrinsic rate of population growth of BNA13 was lower than that of BNB3. Both the intrinsic rates of population growth of BNA13 and BNB3 were the highest at $28^{\circ} \mathrm{C}$ and $4.0 \times 10^{6}$ cells. $\mathrm{mL}^{-1}$ algal density, indicating that some adaptations of the B. calyciflorus sibling species BNA13 and BNB3 in tropical shallow lakes to water temperatures and trophic levels were similar, and they have the potential for coexistence in single waterbody of higher temperature and higher trophic level.

Acknowledgements. This research was funded by Natural Science Foundation of China (grant no. 31200324), Natural Science Foundation of Anhui Province (grant no. 1208085QC47), Natural Science Foundation in College of Anhui Province (grant no. KJ2012A127) and Foundation of Provincial Key Laboratory of Conservation and Utilization for Important Biological Resource in Anhui.

\section{References}

Campillo S., García-Roger E.M., Carmona M.J. and Serra M., 2011. Local adaptation in rotifer populations. Evol. Ecol., $25,933-947$. 
Carmona M.J., Gómez A. and Serra M., 1995. Mictic pattern of the Brachionus plicatilis Müller 1786 in small ponds. Hydrobiologia, 313, 365-371.

Cheng X.F., Xi Y.L. and Li H.B., 2008. Seasonal changes in the genetic structure of a Brachionus calyciflorus population in Lake Liantang based on its sequences. Acta Zool. Sin., 54, 245-255.

Ciros-Pérez J., Gómez A. and Serra M., 2001a. On the taxonomy of three sympatric sibling species of the Brachionus plicatilis (Rotifera) complex from Spain, with the description of B. ibericus n. sp. J. Plankton Res., 23, 1311-1328.

Ciros-Pérez J., Carmona M.J. and Serra M., 2001b. Resource competition between sympatric sibling rotifer species. Limnol. Oceanogr., 46, 1511-1523.

Derry A.M., Hebert P.D.N. and Prepas E.E., 2003. Evolution of rotifers in saline and subsaline lakes: a molecular phylogenetic approach. Limnol. Oceanogr., 48, 675-685.

Dong L.L., Xi Y.L. and Liu G.Y., 2004. Effect of temperature and food concentration on the population dynamics of three Brachionus calyciflorus strains. Chin. J. Appl. Ecol., 15, 2165-2169 (Chinese with English abstract).

Fanestil D.D. and Barrows C.H., 1965. Aging in the rotifer. J. Gerontol., 20, 462-469.

Feng L.K. and Xi Y.L., 2004. The comparative study on the characteristics of the life history of three Brachionus calyciflorus strains. Chin. J. Zoo., 39, 12-15 (Chinese with English abstract).

Fontaneto D., Kaya M., Herniou E.A. and Barraclough T.G., 2009. Extreme levels of hidden diversity in microscopic animals (Rotifera) revealed by DNA taxonomy. Mol. Phylogenet. Evol., 53, 182-189.

Fontaneto D., Iakovenko N. and Eyres I., 2011. Cryptic diversity in the genus Adineta Hudson \& Gosse, 1886 (Rotifera: Bdelloidea: Adinetidae): a DNA taxonomy approach. Hydrobiologia, 662, 27-33.

Garcia C.E., Chaparro-Herrera D.D., Nandini S. and Sarma S.S.S., 2007. Life-history strategies of Brachionus havanaensis subject to kairomones of vertebrate and invertebrate predators. Chem. Ecol., 23, 303-313.

Gilbert J.J. 1999. Kairomone-induced morphological defences in rotifers. In: Tollrian R. and Harvell C.D. (eds.), The Ecology and Evolution of Inducible Defense, Princeton University Press, Princeton, 127-141.

Gilbert J.J. and Walsh E.J., 2005. Brachionus calyciflorusis a species complex: mating behavior and genetic differentiation among four geographically isolatied strains. Hydrobiologia, 546, 257-265.

Gómez A. and Serra M., 1995. Behavioral reproductive isolation among sympatric strains of Brachionus plicatilis Müller 1786: insights into the status of this taxonomic species. Hydrobiologia, 313/314, 111-119.

Gómez A. and Snell T.W., 1996. Sibling species and cryptic speciation in the Brachionus plicatilis species complex (Rotifera). J. Evol. Biol., 9, 953-964.

Gómez A., Temprano M. and Serra M., 1995. Ecological genetics of a cyclical parthenogen in temporary habitats. J. Evol. Biol., 8, 601-622.

Gómez A., Carmona M.J. and Serra M., 1997. Ecological factors affecting gene flow in the Brachionus plicatilis complex (Rotifera). Oecologia, 111, 350-356.

Gómez A., Adcock G.J., Lunt D.H. and Carvalho G.R., 2002. The interplay between colonization history and gene flow in passively dispersing zooplankton: microsatellite analyses of rotifer resting egg banks. J. Evol. Biol., 15, 158-171.

Guo R.X., Snell T.W. and Yang J.X., 2011. Ecological strategy of rotifer (Brachionus calyciflorus) exposed to predatorand competitor-conditioned media. Hydrobiologia, 658, 163-171.

Hu C.B., Xi Y.L. and Tao L.X., 2008. Comparative study on the life history characteristics of Brachionus rubens and B. urceolaris. Acta Ecol. Sin., 28, 5957-5963 (Chinese with English abstract).

Krebs C.J., 1985. Ecology: the Experimental Analysis of Distribution and Abundance, Harper \& Row, New York, p. 800.

Lapesa S., Snell T.W., Fields D.M. and Serra M., 2002. Predatory interactions between a cyclopoid copepod and three sibling rotifer species. Freshw. Biol., 47, 1685-1695.

Li H.B., Xi Y.L., Cheng X.F., Xiang X.L., Hu C.B. and Tao L.X., 2008. Sympatric speciation in rotifers: evidence from molecular phylogenetic relationships and reproductive isolation among Brachionus calyciflorus clones. Acta Zool. Sin., 54, 256-264.

Li H.B., Xi Y.L. and Cheng X.F., 2009. Comparative studies of life history characteristics of three sibling species in Brachionus calyciflorus complex. Acta Ecol. Sin., 29, 581-588 (Chinese with English abstract).

Li L., Niu C.J. and Ma R., 2010. Rapid temporal succession identified by COI of the rotifer Brachionus calyciflorus Pallas in Xihai Pond, Beijing, China, in relation to ecological traits. J. Plankt. Res., 32, 951-959.

Li S., Zhu H., Xia Y., Yu M., Liu K., Ye Z. and Chen Y., 1959. The mass culture of unicellular green algae. Acta Hydrobiol. Sin., 4, 462-472 (Chinese with English abstract).

Meadow N.D. and Barrows C.H., 1971. Studies on aging in a bdelloid rotifer. II. The effects of various environmental conditions and maternal age on longevity and fecundity. J. Gerontol., 26, 302-309.

Montero-Pau J. and Serra M., 2011. Life-cycle switching and coexistence of species with no niche differentiation. PLoS ONE, 6, e20314.

Montero-Pau J., Ramos-Rodriguez E., Serra M. and Gómez A., 2011. Long-term coexistence of rotifer cryptic species. PLoS ONE, 6, e21530.

Ning L.F., Xi Y.L., Sun Q. and Zhou A., 2013. Combined effects of temperature and algal food density on life table demography of Brachionus diversicornis (Rotifera). J. Lake Sci., 25, 295-301.

Ortells R., Gómez A. and Serra M., 2003. Coexistence of cryptic rotifer species: ecological and genetic characterisation of Brachionus plicatilis. Freshw. Biol., 48, 2194 2202.

Pavón-Meza E.L., Sarma S.S.S. and Nandini S., 2005. Combined effects of algal (Chlorella vulgaris) food level and temperature on the demography of Brachionus havanaensis (Rotifera): a life table study. Hydrobiologia, 546, 353-360.

Peltier W.H. and Weber C.I., 1985. Methods for measuring the acute toxicity of effluents to freshwater and marine organisms. EPA/600/4-85/013. United States Environmental Protect Agency, Cincinnati, Ohio.

Pérez-Legaspi I.A. and Rico-Martínez R., 1998. Effect of temperature and food concentration in two species of littoral rotifers. Hydrobiologia, 387/388, 341-348. 
Pfenninger M. and Schwenk K., 2007. Cryptic animal species are homogeneously distributed among taxa and biogeographical regions. BMC Evol. Biol., 7, 121.

Poole R.W., 1974. An Introduction to Quantitative Ecology, McGraw-Hill, New York, p. 532.

Ricci C., 1991. Comparison of five strains of a parthenogenetic species, Macrotrachela quadricornifera (Rotifera, Bdelloidea). Hydrobiologia, 211, 147-155.

Sarma S.S.S., Nandini S. and Gulati R.D., 2002. Cost of reproduction in selected species of zooplankton (rotifers and cladocerans). Hydrobiologia, 481, 89-99.

Segers H., 2008. Global diversity of rotifers (Rotifera) in freshwater. Hydrobiologia, 595, 49-59.

Stearns S.C., 1976. Life history tactics: a review of ideas. Q. Rev. Biol., 51, 3- 47.

Stelzer C., 2005. Evolution of rotifer life histories. Hydrobioloiga, 546, 335-346.

Suatoni E., Vicario S., Rice S., Snell T. and Caccone A., 2006. An analysis of species boundaries and biogeographic patterns in a cryptic species complex: the rotifer-Brachionus plicatilis. Mol. Phylogenet. Evol., 41, 86-98.

Tao L.X., Xi Y.L. and Hu C.B., 2008. Comparative study on the life history characteristics of rotifer Brachionus forcatus and B. caudatus. Chin. J. Appl. Ecol., 15, 2165-2169 (Chinese with English abstract).

Walker K.F., 1981. A synopsis of ecological information on the saline lake rotifer Brachionus plicatilis Müller 1786. Hydrobiologia, 81, 159-167.
Wallace R.L., Snell T.W., Ricci C. and Nogrady T., 2006. Rotifera Part 1: Biology, Ecology and Systematics. Guides to the Identification of the Microinvertebrates of the Continental Waters of the World (Zooplankton Guides), Kenobi Productions, Ghent, Belgium/Backhuys Publishers, The Hague, The Netherlands.

Xi Y.L., Ge Y.L., Chen F., Wen X.L. and Dong L.L., 2005. Life history characteristics of three strains of Brachionus calyciflorus (Rotifera) at different temperatures. J. Freshw. Ecol., 20, 707-713.

Xi Y.L., Xu D.D., Ma J., Ge Y.L. and Wen X.L., 2013. Differences in life table parameters between Keratella tropica and Keratella valga (Rotatoria) from subtropical shallow lakes. J. Freshw. Ecol., 28, 539-545.

Xiang X.L., Xi Y.L., Wen X.L., Zhang J.Y. and Ma Q., 2010. Spatial patterns of genetic differentiation in Brachionus calyciflorus species complex. Zool. Res., 31, 205-220.

Xiang X.L., Xi Y.L., Wen X.L., Zhang G., Wang J.X. and $\mathrm{Hu}$ K., 2011a. Genetic differentiation and phylogeographical structure of the Brachionus calyciflorus complex in eastern China. Mol. Ecol., 20, 3027-3044.

Xiang X.L., Xi Y.L., Wen X.L., Zhang G., Wang J.X. and $\mathrm{Hu}$ K., 2011b. Patterns and processes in the genetic differentiation of the Brachionus calyciflorus complex, a passively dispersing freshwater zooplankton. Mol. Phylogenet. Evol., 59, 386-398.

Zou E.M., 2003. Current status of environmental endocrine disruption in selected aquatic invertebrates. Acta Zool. Sin., $49,551-565$. 